\title{
The open society as a rule-based order
}

\author{
GERALD GAUS \\ University of Arizona
}

\section{1.}

My doctoral supervisor, John W. Chapman, spent his career analyzing why Western Europe developed an open, prosperous, dynamic society. In one way or another every seminar was about that, with our readings ranging over cultural history, economic history, sociology, social psychology, psychology and, yes, even philosophy. "What happened in the West?", he would inquire again and again, seeing parts of the truth in the diverse writings of Douglas North, Clifford Geertz, Zevedei Barbu, Jean Beachler and Fernand Braudel, to name just a very few. In the end, he was never able to weave all the strands into a narrative that, in his judgment, did justice to the problem (or perhaps he glimpsed that it would take over 2000 pages to do so). Deirdre Nansen McCloskey's three-volume work, culminating in Bourgeois equality, is in my view the most compelling grand narrative answering Chapman's query to date. I am entirely convinced on critical points: that the astonishing betterment since (roughly) 1800 is fundamentally a product of the market-tested innovations of the open society, and of the absolutely critical role of moral and ethical notions of bourgeois dignity and equality. On these and many other matters, I have learned immensely from McCloskey's great work, for which I am deeply grateful.

To criticize this polymath's sweeping, learned treatise would seem churlish-and foolish, for there doubtlessly are piles of records and works that show the folly of disputing its claims. Yet, despite McCloskey's attractive grand synthesis, I remain unconvinced about some important matters. The heart of my worries concern a puzzle posed by McCloskey's narrative, the puzzle of the place of virtue in a diverse and open society. "From about 500 BCE to about 1790 CE", McCloskey writes, "the ethical universe was described in Europe as composed of the seven principal virtues, resulting by recombination in 
hundreds of minor and particular virtues" (p. 188). ${ }^{1}$ And, she continues, "Ethical philosophy since the sudden decline of virtue ethics in the late eighteenth century has focused [....] [on] how we treat other people", which concerns only part of virtue (p. 190). McCloskey realizes, I think, the importance of rule-based morality for the open society, quoting Milton Friedman on the importance of "conforming to the basic rules of society, both those embodied in law and ethical custom" (p. 231). Still, conformity with the rules of society is distinct from virtue. The puzzle I wish to address, then, is manifest: the liftoff of the Great Enrichment coincided with the rise of other-concerned rule-based ethics, yet at the core of McCloskey's narrative is the importance of virtue and character, which faded in ethical philosophy just as the Great Enrichment really got going. Perhaps this simply demonstrates how confused philosophical reflection is-abandoning virtue as a core concept in morality just as it was about to change the world. Perhaps just as the owl of Minerva took off, philosophy focused on the poor pigeon of rules of justice. I think not. Certainly a rule-based morality-a social morality based on rules, or social norms, shared by the group to which all expect that others will conform-does not itself make for a prosperous, dynamic, open society. ${ }^{2}$ But I am convinced that we cannot have one without it, and such a morality is more important than a socially recognized set of virtues - which we simply do not have in the diverse societies that spurred the Great Enrichment. I do not claim that McCloskey entirely overlooks the rules of social morality but I believe that because the main foil of Bourgeois equality is the institutionalist explanations of Douglas North and his coworkers, she tends to underappreciate the place of moral and social rules in the grounding of an open society.

2.

2.1. Two well-known lines of reasoning have driven most political philosophers and social scientists away from the stress on virtue that characterizes McCloskey's narrative. Virtue ethics is typically about

\footnotetext{
${ }^{1}$ Unless otherwise indicated, all page references in the text refer to McCloskey (2016).

' I shall not distinguish what I shall call 'social-moral rules' and 'social norms' though McCloskey does: "Norms are ethical persuasions, bendable, arguable, interpretable. Rules are, well, rules, such as that bribes are illegal in Delhi, or that jaywalking is illegal in Evanston" (p. 113). I believe social norms are typically rather more specific than this would suggest, but nothing turns here on this point. On the nature of social morality, see Gaus (2011, chap. 1 and 3).
} 
people's character-whether a person is courageous, temperate or just, yet there is strong reason to doubt whether character traits are powerful explanations of what people actually do. Drawing on the work of Lee Ross, Richard Nisbett (1980) and others, fifteen years ago Gilbert Harman (1999, 2000) caused something of a furor among virtue theorists by presenting well-known research showing that character traits are poor predictors of action. More generally, there is a large body of evidence that attitudes-what people approve of-are weak predictors of their behavior (Bicchieri forthcoming). Cristina Bicchieri draws our attention to a UNICEF study on violence toward children, which reported both high rates of caregiver disapproval of punishment (negative attitudes toward it) and of high rates of punishing behavior (Bicchieri forthcoming). Similar findings have been reported concerning prison guards (Bicchieri 2006, 180). And, as Bicchieri reports, in some African countries there appears to be a similar pattern concerning female genital cutting-high disapproval rates combined with high participation rates (Bicchieri forthcoming). It is important to stress the issue here is not economistic self-interest versus virtue, but social versus individual factors in explaining action (cf., p. 339). If our concern is the emergence of an open society based on mutual respect of each other's liberty and equality-not a concern simply with what is admirable, but what people do-there is strong reason to question the explanatory power of character traits and attitudes. As will become clear, I believe that attitudes and virtues do figure into an adequate account of the emergence of the free, liberal, open society, but they do so in a rather circuitous way, to a great extent through the rulegovernance of social morality.

2.2. The second line of reasoning that has led many to doubt a strong tie between any virtue ethic and the grounding of a modern, diverse moral order is the very heterogeneity of the open society. Following the great nineteenth century moral philosopher Henry Sidgwick (1962, 105-106), Charles Larmore contrasts the modern conception of ethics-founded on the notion of the right-with the view of the ancients, according to which the good is the foundation of ethics:

If the notion of right is replaced by that of good at the foundations of ethics [. . .] then the moral ideal will no longer be imperative, but rather attractive. His [i.e., Sidgwick's] point was that ethical value may be defined either as what is binding or obligatory upon an 
agent, whatever may be his wants or desires, or as what an agent would in fact want if he were sufficiently informed about what he desires. In the first view, the notion of right is fundamental, in the second, the notion of good (Larmore 1996, 20).

As Sidgwick saw it,

[A]ccording to the Aristotelian view-which is that of Greek philosophy generally, and has been widely taken in later times-the primary subject of ethical investigation is all that is included under the notion of what is good for man or desirable for man; all that is reasonably chosen or sought by him, not as a means to some ulterior end, but for itself [...] $(1925,2)$.

Ancient ethics was teleological, a science of ends and virtue; it concerned what a person properly desires or what a proper, virtuous, person desires, or finds attractive. In contrast, modern ethics concerns what we must do-what we are required to do even if we are not attracted to it. The crux of modern "other-regarding" ethics is that it forms the basis of a demand that another, who is often a stranger to me, must act, or refrain from acting, in a certain way whether or not she wishes to, or is attracted by that way of acting. Does she ascribe to bourgeois virtue? I don't know. Must she act in the required way? Certainly.

The very nature of the open society is that one must deal with strangers, who cherish very different ideals, and whose character traits are largely unknown. Those engaged in a cooperative system must know what counts as cooperation-what responses are expected, what constitutes fair dealing, disclosure, prompt payment, and so on. Although sometimes this can be left to individual negotiation, largescale cooperation requires knowledge of the moral rules of the game when we confront total strangers. In most cases we know little about these strangers - in particular, their conception of virtue and how well they live up to what they consider virtuous-yet we need to rely on them. How can that happen?

\section{3.}

It might seem that this line of reasoning leads us to embrace McCloskey's bête noire-"Mr. Max U," the economistic "sociopath" who acts simply to maximize his own utility, with "utility" being understood in terms of self-interest (chap. 21, p. 186). If we are not chiefly moved by 
virtue and character, are we then committed to simple self-interest? If we are, it would seem that social cooperation must depend on the development of institutions that channel self-interested behavior in productive ways. While such institutions are rather more important than McCloskey is willing to acknowledge given her apparent antipathy to North's institutionalism, it nevertheless is true that what economists mean by 'institutions' is but one conception (p. 113). In the last fifteen years a large body of evidence has accumulated that the actions of humans are critically sensitive to the normative expectations of others: we care about what others think we ought to do (Bicchieri and Chavez 2010). ${ }^{3}$ On Bicchieri's influential, empirically-supported analysis, a person often prefers to follow a social rule $r$ because he has a first-order belief that enough others ${ }^{4}$ in his social network follow $r$ and he has a second-order belief ${ }^{5}$ according to which he believes that enough others in the network believe that he ought to follow $r$-neither of these imply that he thinks $r$ is a good, efficient or fair rule. Thus one can follow a social rule of which one does not approve. For a social rule to exist most people have to (i) believe that most others will act on it and (ii) believe that most others believe that it ought to be followed. However, (i) and (ii) do not imply (iii) that any specific person actually believes $r$ is a rule that he ought to follow in the sense that it conforms to his own convictions about virtue or his own personal moral attitudes. A social rule requires that most hold second-order beliefs about what they think others believe they ought to do, but it does not require that all uphold the conception of virtues, or the moral attitudes, expressed by the rule (this accounts for many of the results sketched in section 2).

This, I would conjecture, is an important reason why egalitarian social-moral rules took root so quickly in Western Europe: their emergence did not require that everyone, or even most, embraced the bourgeois virtues or internalized a commitment to bourgeois equality (p. 352). Indeed, no doubt very many did not. It is because we are such deeply social normative creatures, in the sense that we are so attuned to the normative expectations of others, that we can achieve a stable rulebased system of cooperation even when many are not enthusiastic about

\footnotetext{
${ }^{3}$ We are also moved-apparently even more strongly-by what we expect others will actually do. See Bicchieri and Xiao (2008).

${ }^{4}$ What constitutes "enough" others will vary from person to person. Bicchieri (2006, 52 54) models each person as having a threshold value that determines when "enough others" are acting on the norm and have the appropriate normative expectations.

${ }^{5}$ That is, a belief about what others believe.
} 
the moral attitudes and virtues that the rules express. And, as I have said, this can be a great thing in an open society, where we are always encountering new people with new perspectives, many of whom do not share our deep commitments to the bourgeois virtues. What is important is that people generally share beliefs about what others normatively expect of them, and they accept these normative expectations as legitimate.

Thus the critical importance of moral indignation and responsibility-something that McCloskey appreciates (pp. 125, 136, and 167); the latter of which, she informs us, is an eighteenth century innovation (p. 375), so perhaps a critical innovation preparing for the Great Enrichment. When no one holds others responsible for rule conformity cooperative social life is greatly impaired (p. 137). Yet, holding others responsible requires shared normative expectations. There is no sense in me seeking to hold you responsible for breaking a rule when you did not know you were expected to conform, as it is counterproductive to experience moral indignation and outrage at actions that others do not think are prohibited. To be sure, rules are often enforced by punishment, and it is easy to think of indignation simply as punishment. One of the things that we have learned from the work of Ernst Fehr and others is just how important punishment is to maintaining social cooperation (see Gaus 2011, 103-122). Yet we also know that when punishment fails to correspond to what people believe are legitimate normative expectations, punishment easily turns into "anti-social" counter-punishment. As Samuel Bowles and Herbert Gintis $(2011,26)$ stress, effective punishment depends on legitimacy: unless those to be punished and their friends and allies are convinced that the rule being enforced is legitimate, a punishing action taken as a means to protect social cooperation can lead to weakening it. Experimental evidence (e.g., Hopfensitz and Reuben 2009) confirms that attempts at punishment readily evoke counter-punishment when the offender does not experience guilt, which is associated with moral norm violation.

Again, then, we confront the importance of what people consider the legitimate normative expectations of them. We are not talking about "Mr. Max U," who only obeys the rules of society because it is prudent to do so (perhaps because he will be punished if caught). To be sure, there are always some such people, and any effective system of rules must cope with them, but they are generally at the periphery. But we should not jump to the opposite conclusion that most of those who obey social 
rules do so because the rules express their favored moral attitudes and conception of virtues; a critical explanatory variable for many people is their responsiveness to the normative expectations of those with whom they share a social life. I believe that it is, in general, false that everyday moral action requires virtues such as temperance or courage (p. 197), or even the "middling" virtues, except in so far as one must be sensitive to the legitimate expectations of others.

\section{4.}

Most, I think, seem essentially driven by what they expect others will do, and what they believe are the legitimate normative expectations of others. There are others-whom Bicchieri calls "trendsetters"-who are much more apt to act on their own moral attitudes and convictions (Bicchieri forthcoming; Bicchieri 2006, 201-205; Gaus 2011, 441-443). Trendsetting individuals are much more likely to act on their own conception of virtue and their own moral attitudes, and seek to shape the social rules of their society to conform to them. They are less sensitive to the normative expectations of others and more devoted to their own moral attitudes. In my view Bourgeois equality should be read as being about these individuals-how these trendsetters shaped the social rules of northwestern Europe, pushing the rest toward the rulebased "institutionalization" of equal dignity and liberty. It is important that on Bicchieri's account trendsetters are not usually the highest status people (the governing elite, the clerisy) who are at the core of their social networks, but those closer to the periphery, such as the industrious and innovative bourgeois about whom McCloskey tells us so much.

It is fundamental that these trendsetters did not need to convert anything near everyone to their conception of virtue or induce them to share their personal moral attitudes: the critical point is that they were able to shape the social rules that generated normative expectations supporting equal dignity, liberty, markets and innovation, and that these normative expectations were widely accepted as legitimate. For some, this legitimacy might indeed be driven by the sort of self-interest economists are wont to stress (the rules did indeed have beneficial consequences for many). And for many others sheer conformity may be the most important factor-we should never underestimate just how important conformity is to any culture. Rhetoric and attitude change certainly figure into norm change (p. 509), but other factors can be 
critical: for example the changes in norms relating to sexual behavior appear to have been a complicated mix of attitude change and cohort replacement (Scott 1998).

To be sure, as McCloskey so carefully demonstrates, the rhetoric in support of bourgeois virtue and equality thrived in much of the eighteenth and nineteenth centuries (earlier in Holland), and much of this was devoted to inculcating bourgeois attitudes and character. But this does not mean that the success of this rhetorical project required near-universal conversion (which, as we know, never happened) but rather the reconstructing of the "institutions"-the social rules that provide the moral framework for cooperation-that aligned with bourgeois attitudes and character (which, to a large extent, did happen). This fundamentally important point, I think, is sometimes obscured by McCloskey's ongoing battle with self-interest based institutional analysis, which tends to take other forms of rule-based frameworks off the analytical table.

\section{5.}

"To employ an old-fashioned but still useful vocabulary, devised in 1861 by Henry Maine," McCloskey writes, "the northwest of Europe, and Britain in particular, changed from a society of status to a society of contract, at any rate in its theory about itself" (p. 423). The idea of a society based on contract was central to the social contract theories of the sixteenth (Hobbes), seventeenth (Locke), and eighteenth centuries (Kant and Rousseau) - an idea that McCloskey does not adore (a "stream of narrow ethics paired with grand political theory", [p. 185]). Unfortunately, like so many, McCloskey succumbs to a cartoon version of contract theories, in which John Locke and John Rawls present "boys' models" of social ethics as "prudence with-a-version-of-justice" (McCloskey 2011, 192). At least in some ways I am an old-fashioned philosopher; to me an ad hominem is still an ad hominem even when it is ideologically fashionable, so I shall leave rhetoric about guy and gal ethics to others, and instead stress the fundamental contribution of social contract theory to an egalitarian social order.

The social contract insisted that the basic social framework and rules for a society apply universally to the common category of citizen (or, as I have put it in Gaus 2011, chap. 5, "members of the public"). There was not one set of rules for the nobility, another for the merchants, and others for the clergy. Thus Rousseau $(1923,27)$-who is 
a complex and subtle thinker, and should not be read in terms of "good guys and bad guys in philosophy"-stressed that laws consistent with the general will "must both come from all and apply to all". A framework of liberal equality embraces this ideal of universal membership in the community: the rules of basic social life apply equally to all, simply as members of a community. Of course the liberal egalitarian order often fell short of its own promise, for rules persisted and still persist that discriminate and illegitimately classify, but this promise has been one of the great sources of moral improvement in liberal society. Recall Martin Luther King Jr.'s (1963) insistence that the American founders issued "a promissory note to which every American was to fall heir. This note was a promise that all men would be guaranteed the inalienable rights of life, liberty, and the pursuit of happiness". So, King proclaims to the marchers on Washington, "we have come to cash this check-a check that will give us upon demand the riches of freedom and the security of justice".

In practice, of course, social rules and norms specify various roles (e.g., creditor and debtor) that not all will occupy, and so the ideal of universal membership is more complex than merely acknowledging equal status. The social contract's "aim is free agreement" (Rawls 1985, 230)-at least to understand what a society that could be freely agreed to would look like. And so even when the basic framework of society defines different roles and responsibilities, the notion of "bourgeois equality" is manifested as a framework that all free and equal members of the public could accept. Again, this is a regulative ideal-a test by which to judge the bona fides of the liberal order. And, yes, there is never such consent to the basic ethical rules of our society. But the contractarian's inquiry into whether they are fit for such agreement constitutes a public working out of the bourgeois ideal of equality. The social contract's focus on whether everyone's basic interests are catered to is not the upshot of a simple-minded view of humans as only concerned with prudence-a view that no social contract theorist, not even Hobbes, ever held-but a recognition that behind the high moral language of so many social orders has been the reality that some have been subjugated so that others could thrive.

6.

Although contractarian philosophers come in for rather hard treatment, McCloskey is much kinder to the "blessed" Adam Smith, especially the 
Smith of Theory of the moral sentiments, which McCloskey depicts as a forerunner of her own work (p. 644). Yet there too Smith insists on the importance of justice: "Justice [...] is the main pillar that upholds the whole edifice. If it is removed, the great, the immense fabric of human society [...] must in a moment crumble into atoms" (Smith 1853, 125). And thus, "[s]ociety may subsist, though not in the most comfortable state, without beneficence; but the prevalence of injustice must utterly destroy it" (Smith 1853, 125). Because Smith saw so clearly the fundamental role of rules of justice, he took pains to consider what types of rules of justice were essential to a free society, stressing (as did Hayek) the importance of negative rules.

The man who barely abstains from violating either the person or the estate, or the reputation, of his neighbours, has surely very little positive merit [virtue]. He fulfils, however, all the rules of what is peculiarly called justice, and does everything which his equals can with propriety force him to do, or which they can punish him for not doing. We may often fulfil all the rules of justice by sitting still and doing nothing (Smith 1853, 117; cf. Hayek 1960, 150).

Once we see the importance of the "rules of justice" for a free and open society, we open up new lines of inquiry. Following Smith's and Hayek's lead, we might ask what forms of rules are most conducive to a free, open, society. Recent research I conducted with Shaun Nichols (2017) suggests that some ways of teaching moral rules are more conducive to innovation and discovery than others. Rawls notes that although there are, in principle, an indefinite or infinite number of possible moral (or legal) rules, a moral (or legal) conception that seeks to guide behavior supposes a principle of closure or completeness: given such a closure rule, the system of rules can be complete, and provide a full guide to behavior (Rawls 1999, 300-301). Drawing on this idea, John Mikhail (2010, sec. 6.3.1) identifies one closure rule as:

The Principle of Natural Liberty: Whatever is not prohibited (and this includes the non-performance of specific acts) is permitted.

On this closure rule, an agent consults the system of rules and determines whether her action is prohibited by some rule in the system; if it is not, then she is free to act. Now as Mikhail notes an alternative closure rule is: 
Residual Prohibition Principle: Whatever is not permitted is prohibited.

If this is the closure rule, a person is prohibited from acting unless the system of rules permits it. In an obvious sense there is always an onus on a rule-following actor to cite a permission before acting, to show that the Residual Prohibition Principle does not apply.

In a series of experiments, Nichols and I found that subjects taught primarily prohibition rules tended to assume the closure principle of Natural Liberty (if an action is not prohibited, morality allows one to engage in it), while those trained on permission rules tended to suppose that if something is not explicitly permitted, it is prohibited. Thus, we argued, a social morality that stresses prohibitions rather than permissions encourages innovation and exploratory action-the innovator need not show that her innovative activity falls under some preexisting permission, but only that there is no explicit prohibition. And this seems important for markets. As a recent editorial in The Economist (2015) pointed out in relation to the liberalization of Cuba,

In place of a 'positive list' of permitted private activities, the government should publish a negative one that reserves just a few for the state. All others would then be open to private initiative, including professions such as architecture, medicine, education and the law.

My point here is that the intriguing idea that the form of the basic rules of justice deeply matter for open societies and innovative markets does not even occur to the investigator until she appreciates just how important are the rules of justice for an open, innovative, society.

\section{7.}

John Chapman would have been thrilled by Deidre McCloskey's learned, innovative and sweeping narrative, providing innumerable insights backed by a diversity of evidence, all tending to show why the West got so rich, so fast. And that ideas, social ethics, and market innovation are at the core of her account would be as welcomed to him as it is to me. "Jerry," he would have said, "I think she got it right". Yet after more hard thinking and careful thought, he would inevitably conclude, "Well, perhaps not entirely right". But surely that is all any of us can hope for. 


\section{REFERENCES}

Bicchieri, Cristina. 2006. The grammar of society. Cambridge: Cambridge University Press.

Bicchieri, Cristina. Forthcoming. Norms in the wild. New York: Oxford University Press. Bicchieri, Cristina, and Erte Xiao. 2008. Do the right thing: but only if others do so. Journal of Behavioral Decision Making, 22 (2): 191-208.

Bicchieri, Cristina, and Alex Chavez. 2010. Behaving as expected: public information and fairness norms. Journal of Behavioral Decision Making, 23 (2): 161-178.

Bowles, Samuel, and Herbert Gintis. 2011. A cooperative species. Princeton: Princeton University Press.

Gaus, Gerald. 2011. The order of public reason: a theory of freedom and morality in a diverse and bounded world. Cambridge: Cambridge University Press.

Gaus, Gerald, and Shaun Nichols. 2017. Moral learning in the open society: the theory and practice of natural liberty. Social Philosophy \& Policy, 34.

Harman, Gilbert. 1999. Moral philosophy meets social psychology: virtue ethics and the fundamental attribution error. Proceedings of the Aristotelian Society, New Series, 99: 315-331.

Harman, Gilbert. 2000. The nonexistence of character traits. Proceedings of the Aristotelian Society, New Series, 100: 223-226.

Hayek, Friedrich A. 1960. The constitution of liberty. Chicago: University of Chicago Press.

Hopfensitz, Astrid, and Ernesto Reuben. 2009. The importance of emotions for the effectiveness of social punishment. The Economic Journal, 119 (540): 1534-1559.

King, Martin Luther Jr. 1963. I have a dream.... Speech at the March on Washington, 1963. http://www.archives.gov/press/exhibits/dream-speech.pdf (accessed August 2016).

Larmore, Charles. 1996. The morals of modernity. Cambridge: Cambridge University Press.

McCloskey, Deirdre Nansen. 2011. The rhetoric of the economy and the polity. Annual Review of Political Science, 14: 181-199.

McCloskey, Deirdre Nansen. 2016. Bourgeois equality: how ideas, not capital or institutions, enriched the world. Chicago: University of Chicago Press.

Mikhail, John. 2010. The elements of moral cognition: Rawls' linguistic analogy and the cognitive science of moral and legal judgment. Cambridge: Cambridge University Press.

Nisbett, Richard, and Lee Ross. 1980. Human inference: strategies and shortcomings of social judgments. Englewood Cliffs (NJ): Prentice-Hall.

Rawls, John. 1985. Justice as fairness: political not metaphysical. Philosophy \& Public Affairs, 14 (3): 223-251.

Rawls, John. 1999. A theory of justice, revised edition. Cambridge, MA: Harvard University Press.

Rousseau, Jean-Jacques. 1923. The social contract and discourses by Jean-Jacques Rousseau, translated with an introduction by G. D. H. Cole. London: J. M. Dent and Sons.

Scott, Jacqueline. 1998. Changing attitudes to sexual morality: a cross-national comparison. Sociology, 32 (4): 815-845. 
Sidgwick, Henry. 1925. Outlines of the history of ethics for English readers. London: Macmillan.

Sidgwick, Henry. 1962. The methods of ethics, 7th ed. Chicago: University of Chicago Press.

Smith, Adam. 1853. The theory of moral sentiments. London: Henry G. Bohn.

The Economist. 2015. Reforming Cuba. May 16, 2015.

Gerald Gaus is the James E. Rogers professor of philosophy at the University of Arizona, where he directs the program in philosophy, politics, economics \& law. He is also a faculty in the Center for the Philosophy of Freedom. His books include Value and justification (Cambridge University Press, 1990), Justificatory liberalism (Oxford University Press, 1996) and The order of public reason (Cambridge University Press, 2011). His most recent book is The tyranny of the ideal: justice in a diverse society (Princeton University Press, 2016). He is currently writing a book, An evolving moral order: Hayekian social philosophy for the twenty-first century to be published by Oxford University Press. His papers can be found at http://www.gaus.biz. Contact e-mail: <jerry@gaus.biz> 